\title{
DISCOURSE ANALYSIS OF PB DJARUM VS KPAI POLEMIC REPORTED BY 3 MASS MEDIA (CNN INDONESIA, DETIK, AND KOMPAS.COM) DURING THE PERIOD OF SEPTEMBER - OCTOBER 2019
}

\author{
Adeline Setiawan ${ }^{1}$, Brigitta Daisy Adela ${ }^{2}$ \\ ${ }^{1,2}$ Post Graduate Programme of Communication and Business Institute London school Public \\ Relation, Jakarta, Indonesia \\ e-mail: adelset27@gmail.com ${ }^{1}$, brigitta.adela@gmail.com²
}

\begin{abstract}
This study analyzes and investigates several online news launched by 3 mass media (CNN Indonesia, Detik, and Tirto) related to PB Djarum vs KPAI Polemic in September 2019, using Van Dijk's discourse analysis. It aims was to explore how different each article used its standpoints in reporting the issue, by looking at Text, Social Cognition, and Context dimensions. In text dimensions, it examines how the articles constructed through micro structure, super structure, and macro structure. Moreover, it is also trying to look beyond the written text, while analyzing in social cognition and context dimensions. This study concludes that the media, in this case the online news media, can be a powerful channel to influence readers through its construction of the polemic issue. As the tobacco industry still known as the main sponsor of badminton-coaching industry in Indonesia, most of the media were portraying positive image of PB Djarum.
\end{abstract}

Keywords: Discourse analysis, Mass Media, Text, Social Cognition, Context Dimension, Van Dijk's,.

\section{INTRODUCTION}

Indonesia is renowned as the "Disneyland" for tobacco industry. This is because Indonesia does not ratify the World Health Organization Framework Convention on Tobacco Control (WHO FCTC) yet and the regulation for tobacco control is still considered weak. Due to these two factors, tobacco industry can easily find loopholes to market their products, one of the ways is through advertising, promotion, and sponsorship.

In 2017, tobacco industry spent around IDR 5.4 trillion (equivalent to USD 3.8 million) for television commercials alone [Anggraeni, 2018, February 1]. In many sporting events such as soccer, badminton, and basketball tournaments, tobacco industry has been their regular, main sponsor. These sponsorships are considered as marketing tactics to normalize tobacco consumption and to promote their products to spectators, that includes children and youths.
A study by Vaidya S. and Vaidya J. (1996) shows that there's a correlation between tobacco sponsorship on cricket matches and children's experimentation with tobacco [Vaidya et al., 1996]. World Health Organization (WHO) is aware of these marketing strategies can affect adolescent's perception and behavior towards tobacco consumption, therefore $\mathrm{WHO}$ created article 13 of WHO FCTC which emphasizes total ban on tobacco advertising, promotion and sponsorship (TAPS BAN) ["Enforce bans on tobacco", n.d.].

According to International Union Against Tuberculosis and Lung Disease (The Union), applying tobacco-free sport policy is crucial for all countries as tobacco is considered as the world's leading killer, thus it has no place in any sporting event. The application of tobaccofree sport includes four key elements: (1) smoke-free area, (2) ban on tobacco 
advertising, promotion, sponsorship, and sale, (3) ban on tobacco funding for events and scholarship, and (4) quit smoking help.

However, this policy and guideline are not fully implemented in Indonesia. This partial implementation has brought up a recent issue of PT. Djarum TBK's sponsorship on badminton scholarship, under the name Perkumpulan Bulu Tangkis Djarum Foundation (PB Djarum Foundation). It all started when PB Djarum held Audisi Umum Djarum Beasiswa Bulutangkis 2019 (Djarum General Badminton Audition 2019) in five cities: Bandung, Purwokerto, Surabaya, Solo Raya, and Kudus. Two days before the first stage of audition in Bandung, on July 26, Lentera Anak and Smoke Free Bandung responded. Both Lentera Anak and Smoke Free Bandung consider this as a way to promote Djarum's brand image since the font used on children's T-shirt is exactly the same as the font used for Djarum's cigarette packs and branding.

Komisi Perlindungan Anak Indonesia (KPAl; Indonesian Children Protection Commission) confirms that this is form of child exploitation. Djarum was considered violating Government Regulation (PP) 109/2012 for using children's bodies as a form of promoting Djarum's brand image which is associated with cigarettes, harmful and deadly product. Regardless of the protest, Audisi Umum PB Djarum was still held in Bandung on July, 28 2019. KPAI did not take this lightly and so under Sitti Hikmawatty, KPAI Commissioner, a coordination meeting was held with Kemenko PMK (Coordinating Ministry for Human Development and Cultural Affairs), Bappenas (Ministry of National Development Planning), KPPPA (Ministry of Women Empowerment and Child Protection), Kemenkes (Ministry of Health), and Kemenpora (Ministry of Youth Affairs and Sport). During the coordination meeting, a number of governmental and nongovernmental organizations were also present: BPOM (National Agency of Drug and Food Control), Yayasan Lentera Anak, Komnas Perlindungan Anak (National Commission for Child Protection), as well as Pokja Tobacco Control-KPAI. The result of the meeting showed a unanimous agreement that Audisi Umum PB Djarum must be withheld as a form of sanction due to their violation of regulations. Early September 2019, Yoppy Rosimin, Program Director of PB Djarum, responded by promising to take down all brand image attributes during the second audition in Purwokerto on September 8 - 10. Yoppy stated that PB Djarum would fulfill KPAl's requests by fully taking down all marketing material that shows PB Djarum's brand image and also stop distributing T-shirts with Djarum logo to the auditioning children.

During the second audition in Purwokerto, PB Djarum did not fully discharge their brand image as the whole committee still wore T-shirts with Djarum logo on it. As KPAI brought up the violation, PB Djarum countered by announcing their decision to discontinue the Audisi Umum Djarum Beasiswa Bulutangkis in 2020 [Nurmansyah, 2019, September 10].

To address the polemic issue of KPAI vs. PB Djarum, this study uses qualitative method and an approach of Van Dijk's Critical Discourse Analysis (CDA) to investigate the structures behind the online news reports which created the polemic. Writers selected several news reports to be investigated. Writers' aim was to explore how different each article used its standpoints in reporting the issue. Discourse analysis consists of some stages of process, writers' analysis involved each of the news media initially reading the news reports independently, and discussing impressions to gain a shared understanding of the reports. After that, writers read through each detail of the reports, examining each word, sentence and paragraph to see the relation on each report to get an overall image of the spread of language elements used.

According to Van Dijk, the mass media today still have a significant role for the readers, to produce and reproduce the talks about ideologies of the markets, politics, policies, exploitation, and marginalization [Van Dijk, 1995, p.28].

Specifically, writers address the following questions:

What do the news media reports about the issue of KPAl vs. PB Djarum 'do' in social interaction? Do they invite dialogue with stakeholders? Do they present a narrative about company's activities? Do they put forward a particular argument about how the company does - or could - deliver tobacco control outcomes in sport events in Indonesia?

To what extent does the content - or what is discussed in these reports - influence how these reports contribute to tobacco control issue in sport events? Writers wished to find if the intention is towards dialogue - how accessible are the reports, and to what extent can stakeholders engage in this dialogue? If the report presents an argument - are there opportunities to challenge the tobacco companies branding policy? 


\section{METHOD}

According to Van Dijk, the term 'discourse' usually refers to a form of language use, public speeches or more generally to spoken language or ways of speaking. The term may also be found in the media. In sum, discourse studies are about talk and text in context. In theoretical description, discourse analysts need to describe a discourse from what such language use it consists of, what its components are, how these components are ordered, or how they may be combined into larger constructs [Van Dijk, 1997, p.5].

Van Dijk's Critical Discourse Analysis contains of 3 dimension of discourse, which are: (1) Text Dimension, (2) Social Cognition Dimension, and (3) Context Dimension.

Table 1. Van Dijk's Critical Discourse Analysis

Macro Structure

Contains of global definition of the text, can be observed from the topic/ theme.

Super Structure

Contains of the structure of the text, such as Introduction, Contents, Closing Part, Summary.

\section{Micro Structure}

Contains of local definition of the text, can be observed from the words chosen, sentences, and style used in the text.

In Text dimension there are text structures and discourse strategy, which the writing production process can be observed by individual cognition of the writer(s). Text dimension is all kind of languages, not only words used in the articles, but also all forms of expression used in the topic.

Social Cognition dimension is making sense many other notions used belong to not only to the realm of discourse structures, but also that of the mind. To understand the users opinion and ideologies in the coherence between sentences and the variation of style used, thus contribute to the construction of new ones or the modification of existing ones with their recipients [Van Dijk, 1997, p.17].

In Context dimension, researchers observe about public trends about the specific problem. There is local and global structures of contexts, for instance, the setting (time, location, circumstances), participants and their various communicative and social roles (speaker, chairperson, friend, etc.), intentions, goals, purpose, and so on [Van Dijk, 1997, p.19]. Context dimension is all situations other than texts and languages those are significant and influencing the production process. For example, the situation where the text was produced at that time.

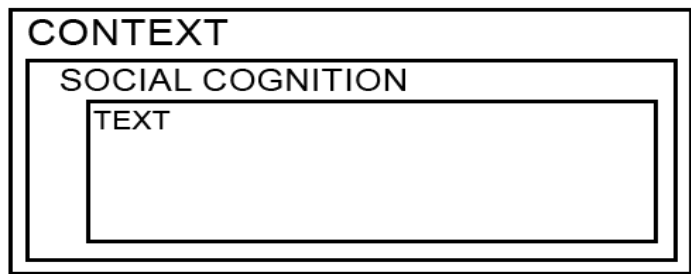

Figure 1. Context Dimension

Moreover, Text Dimension is described in more detailed structures. In this study, writers will analyze each of PB Djarum vs KPAI polemic chosen articles through Van Dijk's model of discourse dimensions, to observe the rhetorical and persuasion process of each of the articles, and whether the articles are choosing some specific words to give their message to the readers.

\section{RESULT AND DISCUSSION}

CNN Indonesia's article "Sejumlah Salah Kaprah dalam Polemik PB Djarum vs KPAF" (Some misunderstanding in PB Djarum vs KPAI Polemic), which written on September 11, 2019, explained 3 points that readers "should understand"; (1) That Indonesian government does not have to be responsible for financing badminton youth candidates training, that since a long time ago, the responsibilities goes to clubs, including PB Djarum. Moreover, CNN also pointed out that budget allocation from 
Indonesian government would be never ideal for youth sport candidates training. (2) PB Djarum needs branding. It does not say it directly, but the article clearly pointed out that it is wrong to assume that if $P B$ Djarum was genuine, there is no need to do branding, by explaining that PB Djarum, Djarum Foundation and Djarum as tobacco producer are all different to each other. Moreover, the article continues by explaining a long history of how PB Djarum was established as club and how it run public audition as it's way to choose candidates to be trained, and finally, describes the reason of why it objected to totally stripped out its attribute on candidate's T-shirt, because of its "historical" background. (3) That PB Djarum would not stop searching badminton candidates despite of the termination of it's public audition. It is said that the next year, PB Djarum will continue its commitment towards the young athletes training by some other "ways" that would not be public audition. Without public audition, candidates overseas Java island must work harder to be seen by PB Djarum coaches.

In text dimension, CNN Indonesia is clearly showing positive image of PB Djarum. Writers assume that there was a symbiosis between the media, PT. Djarum, and the government. Smartly structured, CNN did not show PB Djarum's positive image or it's role at first paragraph, instead, it is only saying that the polemic has been going on as a hot topic, and therefore the article wanted to "straighten" some misunderstanding. In the first point, as the article was written after the statement of Menpora (Minister of Youth and Sports) [Majid, 2019, September 9] that saying the PB Djarum Public Audition should keep going on and there was not any children exploitation, this point in the article tried to appeal supportive to the minister's statement. Clearly, Menpora was objected if the audition stopped because of the issue, showing a gesture that the government was not ready to take a full responsibility of financing the youth candidate training, replacing PB Djarum club. Therefore, the first point written in the article is suggesting the public not to blame the government. This way, it can be appeal that PB Djarum does not want to burden the government, instead, PB Djarum club has been helping the government all over these times.

On the second point, it is said that it is wrong to assume that if $P B$ Djarum was genuine, there is no need to do branding. Firstly, what is branding? According to Brandingmag website, branding, by definition, is a marketing practice in which a company creates a name, symbol or design that is easily identifiable as belonging to the company. It is what makes a memorable impression on consumers, allows your customers and clients to know what to expect from your company. It is a way of distinguishing yourself from the competitors and clarifying what it is you offer that makes you the better choice [Smithson, 2015, October 14].

By putting attribute and name on the public audition, it is clearly a way of branding for any company with the name "Djarum". It does not matter whether it is PT. Djarum, Djarum Foundation, or PB Djarum. The article only explained that PB Djarum could not change the audition name because of a historical background of the name. The government law already mention that Tobacco brand must not include its brand attributes and name while sponsoring events [Kompas.com, 2013, May 31]. So, why is it wrong to assume that PB Djarum should not do branding while sponsoring an event?

On the third point, it is described that PB Djarum will not stop searching badminton candidates despite of the termination of it's public audition. Of course, PB Djarum does not want to appear sulky or in a bad mood. Every company wants to appear strong, dependable, and stable. There would be no problem with PB Djarum, it is just the poor, little young candidates outside the Java island those will struggle even more to be seen by PB Djarum coaches. So, why would the readers burden these young, prolific, achievers-to-be athletes, just because of one word of the name of the badminton audition has violated the law? Clearly, the article is trying to touch an emotional side of the readers. Without putting it into words, the article is describing that $\mathrm{PB}$ Djarum had been helping many Indonesian lives, those brilliant badminton candidates, young athletes who were far from the training facilities and who need some support to continue their training.

Another noticeable point in CNN Indonesia's article, that it used pictures of $\mathrm{PB}$ Djarum events and a picture of Menpora, who was supporting PB Djarum. The last picture before the end of the article, even showing an emotional image of a kid hugged by a man, who are both crying in Public Audition event. There is no picture of KPAI at all.

DetikNews covered Djarum vs KPAl case in their "Pro Kontra" section with the title "PB Djarum vs KPAl soal Audisi Badminton Disetop, Bagaimana Pendapat Anda?" (PB Djarum vs KPAI Regarding the Discontinuance of Badminton Audition, What is Your Opinion?) 
on September 9, 2019. DetikNews stated three points of view for readers to consider and gives opinion, the first one is from the viewpoint of PB Djarum that (1) PB Djarum decided to discontinue General Badminton Audition because they feel they cannot accommodate the inconsistent requests from KPAl. Yoppy Rasimin, Program Director of PB Djarum, claimed that PB Djarum had been cooperative by taking down all marketing material with Djarum brand image and stopped handing out Djarum T-shirt to the children.

From the perspective of KPAI, DetikNews wrote that (2) KPAl did not intend to dismiss PB Djarum Badminton Audition, but to support the development of Indonesian children's talents without violating governmental regulations. Susanto, Head of $\mathrm{KPAI}$, stated that KPAI was framed as if they prohibited the course of badminton audition but it's the governmental regulations such as PP 109/2012 article 35, 37 and 47 that prohibit it. According to article 35 , regulating the promotion of tobacco products is carried out by restricting the usage of logo and/or brand image of tobacco products in an institution and/or individual activity. Meanwhile, article 37 states that everyone who produces or imports tobacco products and gives sponsors in the form of Corporate Social Responsibility (CSR) should follow these following conditions: a. does not use the trademark name and logo of the tobacco products including the brand image; and b. does not aim to promote tobacco products. Lastly, article 47 states that any organizer of activities sponsored by tobacco products and/or aims to promote tobacco products is prohibited from involving children under the age of 18 .

The viewpoint of Menpora (Ministry of Youth and Sports) is also covered by DetikNews. Imam Nahrawi, Minister of Youth and Sports, stated that (3) the Research Bureau of the Ministry of Youth and Sports Law (Kajian Biro Hukum Kemenpora) finds there is no such thing as child exploitation in PB Djarum Badminton Audition. Imam fully supported the continuity of the badminton audition as he felt there's no violation done by PB Djarum.

As DetikNews put this article under their section called "Pro Kontra", they are reporting the polemic between PB Djarum and KPAI in a neutral manner. Although DetikNews shows 2 perspectives (PB Djarum and Menpora) that are in opposition to the charge of child exploitation and only 1 perspective (KPAI) that points out the presence of violation due to child exploitation, they do not attempt to direct people's opinion due to a bias inclination to particular party. Overall, DetikNews is stating both parties' arguments using direct quotations and summarization.

On September 9, 2019, Kompas.com wrote an article with the title "Polemik PB Djarum vs KPAI yang Berujung Stop Audisi..." (Polemic between PB Djarum vs KPAl which resulted in discontinuation of audition...). There are four opinions from four different sources: PB Djarum, KPAI, Menpora, and Pengurus Pusat Persatuan Bulu Tangkis Seluruh Indonesia (PP PBSI). From the viewpoint of PB Djarum, Yoppy Rosimin claimed that (1) PB Djarum tried to find middle ground in keeping "Djarum" name as a part of Badminton Audition but at the same time not violating any regulation. PB Djarum set meetings with several institutions such as Kemenko PMK, Kemenkes, Kemenpora, and KPAI but cannot find the best solution. As KPAI requested for total ban of "Djarum" logo and brand image on all auditions, PB Djarum decided to discontinue their badminton audition starting 2020. Yoppy and PB Djarum claimed that Djarum Foundation is not tobacco product and refused to be associated with Djarum's brand image. On the other hand, from the perspective of KPAI represented by Sitty Hikmawatty, they believe that (2) PB Djarum's audition is a disguised form of promoting Djarum's brand image by using children through sponsorship, and this can be considered as child exploitation. On the 1st of August 2019, KPAl held a meeting with Kemenko PMK, Kemenpora, Kemenkes, Bappenas, and BPOM which resulted in 6 unanimous agreements:

1. In agreement that development of children's interest and talent in badminton should be supported

2. In agreement that Djarum Foundation has to immediately stop using children as a promotion media for Djarum's brand image

3. In agreement to support Indonesian Minister of Women's Empowerment and Child Protection in evaluating Kota Layak Anak (Child-friendly Cities) as the location of Djarum's audition

4. In agreement that KPAI together with Komisi Pemberdayaan Perempuan dan Perlindungan Anak (KPP-PA) will invite the Kepala Daerah (regional heads) who are hosting Djarum's audition

5. In agreement to encourage business owners, especially state-owned enterprises (BUMN), to sponsor talent- 
development activities including sports activities

6. In agreement to encourage parents educating children about the harms of latent smoking, including the usage of cigarette's brand image and the harms of other hidden exploitation in activities involving their children

From the perspective of Kemenpora, represented by Imam Nahrawi, they believe that (3) sport industry needs sponsorship from private companies and evaluated that PB Djarum's audition is not a form of child exploitation. Head of PP PBSI, Wiranto, gave comments regarding this polemic. He said that (4) this polemic between PB Djarum and KPAI should not have happened in the first place. PP PBSI is currently designing a new concept in finding new, excellent talents for badminton industry.

Implicitly, Kompas.com shows their incline towards PB Djarum instead of staying neutral in reporting this polemic. Firstly, the choice of words for their article's title can lead readers into thinking that this polemic ended in an inhospitable manner. The first two paragraphs (shown below)

"Persatuan Bulu Tangkis Djarum secara resmi menghentikan audisi pencarian bakatnya mulai tahun 2020 Keputusan tersebut diambil usai Komisi Perlindungan Anak Indonesia ( KPAI) menilai ajang tersebut memanfaatkan anakanak untuk mempromosikan merek Djarum yang identik dengan produk rokok."

(PB Djarum has officially discontinued their badminton audition starting 2020.

This decision was made after the Indonesian Child Protection Commission (KPAl) assessed that this event is using children to promote the Djarum brand which is associated with tobacco products.)

This text also lead reader's opinions into thinking that KPAI is the cause of this discontinuation. Kompas.com also only points out the support of netizen on Twitter through hashtag \#BubarkanKPAI, even though there are netizen who also support KPAl through \#KamiBersamaKPAI. Although this article reviews four opinions from four perspectives, Kompas.com mainly writes from the perspective and arguments of PB Djarum. Overall, writers feel that Kompas.com should be more neutral in covering the polemic.

\section{CONCLUSION}

Media had constructed the news about PB Djarum vs KPAl polemic, by firstly positioning as if PB Djarum decide to stop its
Public Audition, the Indonesian badminton clubs will decline and die, therefore it sparked mass online debates. After the polemic started, media continued to dig on this alarming, worrying news of how crucial it is to keep PB Djarum run its Public Audition, instead of digging on the original issue that PB Djarum had violated law.

Moreover, in the middle of the heated-up polemic situation, writers presume that $\mathrm{PB}$ Djarum had been using the opportunity to spread its positive image through media. Through analyzing the articles, many media had positioned PB Djarum as a hero, a helper to the government, instead of portraying it as a law offender. Some articles even implicitly presenting a positive narrative about PB Djarum's long history and legacy, giving a rationale "to straighten up" some misunderstandings as well as purposely exposing and pointing out about how Menpora and other government or public figures had showed their supporting gesture to PB Djarum. This will just gave even more powerful public impression of how strong the tobacco industry in Indonesia, or a belief that PB Djarum may be the only business which can replace the government position to support Indonesian badminton clubs.

The findings of writers' analysis may be challenging as well as being seen as critical for tobacco industry efforts to show their positive image through media. Our aim was to provide insights for the readers to understand how media had positioned the tobacco industry in their articles towards sports in Indonesia. When a tobacco company was positioned as being hero and helper for a long time by the media, it has power to diverse a negative claim about it into a bigger issue, such as the termination of PB Djarum Public Audition, which is worse and more threatening than any other issues in the world of Indonesian sports. More work needs to be done, however, in encouraging dialogue and extending these findings

\section{REFERENCE}

Anggraeni, K. [2018, February 1]. Nielsen: 2017, Belanja Iklan Rokok Tembus Rp 5,4 Triliun [Web log post]. Retrieved from https://bisnis.tempo.co/read/1056449/niel sen-2017-belanja-iklan-rokok-tembus-rp54-triliun/full\&view=ok

CNN Indonesia. [2019, September 11]. Sejumlah Salah Kaprah dalam Polemik PB Djarum vs KPAI [Web log post]. 
Retrieved

from https://www.cnnindonesia.com/olahraga/2 0190911040905-170-429320/sejumlahsalah-kaprah-dalam-polemik-pb-djarumvs-kpai

Enforce bans on tobacco advertising, promotion and sponsorship. [n.d.] Retrieved January 30, 2020 from https://www.who.int/tobacco/mpower/enfo rce/en/

Kompas.com. [2013, May 31]. Begini Aturan Iklan Rokok [Web log post]. Retrieved from

https://lifestyle.kompas.com/read/2013/05 /31/15332953/begini.aturan.iklan.rokok

Kompas.com. [2019, September 10]. Polemik PB Djarum vs KPAl yang Berujung Stop Audisi... [Web log post]. Retrieved from https://nasional.kompas.com/read/2019/0 9/10/06234511/polemik-pb-djarum-vskpai-yang-berujung-stop-audisi?page=all

Majid, A. [2019, September 9]. Tegaskan Tak Ada Eksploitasi Anak, Menpora: Audisi Djarum Tidak Boleh Berhenti [Web log post]. Retrieved from https://www.tribunnews.com/sport/2019/0 9/09/tegaskan-tak-ada-eksploitasi-anakmenpora-audisi-djarum-tidak-bolehberhenti

Nurmansyah, R. [2019, September 10]. Begini Kronologi Polemik PB Djarum dan KPAI [Web log post]. Retrieved from https://www.suara.com/sport/2019/09/10/ 140007/begini-kronologi-polemik-pbdjarum-dan-kpai

Smithson, E. [2015, October 14]. What Is Branding And Why Is It Important For Your Business? [Web log post]. Retrieved from

https://www.brandingmag.com/2015/10/1 4/what-is-branding-and-why-is-itimportant-for-your-business/

Tim detikcom. [2019, September 5]. PB Djarum vs KPAl soal Audisi Badminton Disetop, Bagaimana Pendapat Anda? [Web log post]. Retrieved from https://news.detik.com/pro-kontra/d4698629/pb-djarum-vs-kpai-soal-audisibadminton-disetop-bagaimana-pendapatanda
Vaidya, S. G., Naik, U. D., \& Vaidya, J. S. [1996]. Effect of sports sponsorship by tobacco companies on children's experimentation with tobacco. BMJ, 1996[313], 400-416. doi: 10.1136/bmj.313.7054.400

Van Dijk, T. [1995]. The Mass Media Today: Discourse of Domination or Diversity? Javnost - The Public: Journal of the European Institute for Communication and Culture, 2[2], 27-45. doi: 10.1080/13183222.1995.11008592

Van Dijk, T. [1997]. Discourse as Structure and Process. London: SAGE Publication.. 